\title{
CHAPTER X
}

\section{Blood and bone}

Recognition of kinship rests upon notions of shared substance, which are differently formulated from society to society. In this chapter, I show how Toraja conceptions of inherited substance are articulated with house membership, rights of inheritance, and the ceremonial obligations which both of these involve. The images used to speak of these things are revealing of how relationships and responsibilities are thought of, and hence of 'kinship' as an ideology shaping the social world within which people act.

Anthropological analyses of kinship have traditionally taken the system of terminology as a starting point. But the terminology of a cognatic system like that of the Toraja appears to be so simple that it can at best give only a very hazy impression of how kinship actually functions in everyday life. In practice, we find that how terms are actually used often bears little relation to genealogical reality. Rather than constructing formal models derived from terminology, then, I am concerned with what Bourdieu (1977:37) has called 'practical' as opposed to 'official' kinship. Kinship provides a set of ideas that carry moral force and which are put to tactical use in daily life (Bloch 1971b). Pursuing a similarly processual line of analysis, Benjamin (2004) proposes that kinship systems be thought of as providing distinctive modes of consciousness, which mediate people's actions in the world and shape group strategies and identities in subtle yet far-reaching ways. It has been repeatedly pointed out, too, that 'kinship', often essentialised in anthropology as the foundation of social organization, is often difficult to separate from other forms of relatedness, an argument recently re-explored by Carsten (2000). If control over land or other assets such as titles is important, economic considerations may powerfully influence an individual's strategies where kin and marriage relations are concerned. The non-genealogical extension of kin terms in the Toraja context does not function to assign people to particular categories, but rather is intended to convey a certain quality of behaviour; it is used with what Pitt-Rivers (1968:408) has called 'figurative' rather than 'fictive' intent. Rather than viewing 'kinship' as a bounded domain, a more processual approach to the actual uses of kin terms makes it easier to perceive where 'kinship' merges into other modes of thinking - those to do with precedence, rank or gender, for instance. 
Approaches to Indonesian kinship systems have changed and developed radically since the early 1990s. Viewed in terms of an earlier concern with descent as an organizing principle, the societies that have bilateral systems (for example Malays, Javanese, and many Borneo and Sulawesi groups) were negatively judged in terms of absences, such as the lack of descent groups, while the systems of Sumatra and eastern Indonesia appeared to be riddled with inconsistencies because of the many different ways of tracing allegiances which give rise to 'descent groups' of highly irregular composition. In the effort to typologise, it has been problematic even to know how to label some of these societies; some Sumatran systems, in particular, have been subject to multiple and conflicting interpretations. Watson (1991), arguing the need for greater intellectual agility on the part of anthropologists, shows how Kerinci kinship can be interpreted as simultaneously cognatic and matrilineal, and warns against the predetermined and limited perspectives we may impose on ourselves in our enquiries when we apply labels and then work from them. However, as Reuter (1992:490) points out, he does not actually break away from these categories altogether, nor does he get as far as specifying the common features which might underlie such divergent categorizations and help us to make further sense of them. In my own work I have argued that what is needed is to return the focus to indigenous principles, themes and priorities. This offers us the opportunity to make sense of the apparent inconsistencies of these systems, and to see parallels even in systems whose surface features appear highly divergent. Reuter's reanalysis of Sumatran systems is a useful example of how profitable such an approach can be. Instead of seeing Sumatra as 'a fragmented image in the distorting mirrors of conventional kinship theory' (Reuter 1992:518), he is able to draw attention to many recurrent themes that show obvious parallels with eastern Indonesian alliance systems. These include a deep concern with origins, traced along 'pathways', the idea of a 'flow of life' interpreted sometimes into a historical sequence of marriages, and sometimes a historical route of migration and settlement, the use of such pathways and sequences to make claims of precedence, the contestation of these claims by means of alternative narratives, and the basing of status claims on closeness to a 'source'. He also notes the ubiquitous use of botanical idioms to represent kin relations, especially the diachronic relations between 'trunk' and 'tip', founder and branch settlements or houses, and the similarly prominent concern with topogeny or place names, intertwining with and sometimes replacing a concern with genealogy. His analysis argues strongly for a move away from an obsession with formal models (which have usually been presented in a synchronic, ahistorical manner) to a view of kinship as a historical succession of events, creating lines of precedence. The parallels with eastern Indonesia may not surprise us; what is far more remarkable is the ease with which one could extend his argument to show 
how many of these themes are equally significant in a system like the Toraja one, which on the surface appears radically different. Underlying principles, then, create unifying threads between Indonesian kinship systems, while enabling the generation of many variant patterns. ${ }^{1}$ In Sumatran systems, for instance, a unilineal principle is modified by the possibility of exercising alternative options in type of marriage, residence, and resulting allegiances to houses and groups of kin; in a bilateral system like the Toraja, the options are kept open to begin with. Where a patrilineal principle predominates, for instance, (as among the Batak and Besemah) one can prevent the dying out of a house in the absence of male descendants by having recourse to an inmarrying son-in-law; in a system like the Toraja one, the bilateral tracing of descent makes it practically impossible for a house to be left without descendants. The strength of this fresh approach to Indonesian kinship systems lies in its fuller engagement with indigenous concepts, making for a more accurate depiction of how they function, and are seen to function by the peoples themselves. One might perhaps fear that this concentration on indigenous categories could hinder generalization by leading us to become lost in the particularities of each case, but in fact, it is precisely this that, by revealing the underlying contours of shared themes and principles, is making it possible to move toward a new synthesis.

Whereas an older approach to kinship led anthropologists to see cognatic systems as uncomfortably 'amorphous', and to search in vain for group boundaries in the face of the unrestricted tracing of descent, I want specifically to argue that many of the apparent 'problems' of this type of system disappear once we see the house as the real focus of kinship organization. The idea of 'house societies', or more literally 'societies with houses' (sociétés à maison), was originally proposed by Claude Lévi-Strauss $(1983,1987)$ in his discussion of the kinship systems of the North-West Coast of North America, which had troubled an earlier generation of anthropologists by their apparently promiscuous application of contradictory principles. The implications of Lévi-Strauss' argument for Indonesian kinship systems in general, and the Toraja in particular, is a question which I have explored in detail in earlier work (Waterson 1986, 1990, 1995a, 1995b, 1997, 2003), and space prevents me from rehearsing the comparative arguments here; my intention is rather to convey how Toraja think about kinship substance and relationships. Let it suffice briefly to summarise Lévi-Strauss' insights. He proposed that societies where the house was the main focus of kinship organization might be found over a wide temporal and geographical span (including island South-East

$1 \quad$ Fox (1985) already took an important step in this direction by showing how a variety of regional developments in kinship systems could be generated by means of fairly minor modifications in the same basic set of original Proto-Austronesian kin terms. 
Asia, Melanesia and Polynesia as well as feudal Europe and Japan). Houses in such societies typically share a set of features: they are named; they are the possessors of both material and immaterial wealth (such as land, titles, heirlooms or ritual prerogatives); they must be perpetuated over time and not allowed to disappear, at least from memory; they may be elaborately decorated; and they are the sites for ceremonial performances. People trace their descent from house founders, but often in very irregular pathways utilizing both male and female ancestors. The continuity of the house and the transmission of its valuables is 'considered legitimate as long as this continuity can express itself in the language of kinship or of affinity and, most often, of both' (Lévi-Strauss 1983:174). In considering the potentials of the 'house society' concept for an understanding of Indonesian systems, I have argued that we must always take into account how far the 'house' is a salient category for people themselves. Slow as I was to arrive at this realization in my own fieldwork, once I did so, the interpretation of Toraja kinship as a house-focused system was irresistible. The tendency of Toraja to phrase relationships in terms of 'house' metaphors is particularly noticeable. It will be seen how kinship is always being put to use to trace connections with houses; conversely, connections through houses come to stand in for genealogical ties which have been forgotten.

\section{The inheritance of kinship substance}

When Toraja speak about kinship substance, they most often use the term rara buku ('blood [and] bone'). It is this shared substance that binds kin together, and many expressions exist to remind people that the bonds of blood and bone should never be denied, nor be allowed to break or wear out. On the contrary, they should preferably be reinforced through periodic marriages between suitably 'distant' cousins, which at the same time renew the connections between related houses of origin.

It accords with the bilateralism of Toraja kinship principles that rara buku was emphatically stated by all my informants to be indivisible and inherited equally, in an undifferentiated manner, from both mother and father. This point is of significance because, as has been shown by Lévi-Strauss (1969: 393-405), Leach (1961), Fox (1971a:245) and others, in a number of Asian societies bone and blood are symbolically differentiated as 'male' and 'female' substance respectively, bone being said to be inherited from the father at conception and blood or flesh from the mother. Lévi-Strauss proposed that these ideas appear in marked association with systems of generalized exchange, in which kin groups associated as bride-givers and bride-receivers only supply one of these substances to any particular partner group. In such cases 
bone is commonly associated with the desired permanence of descent lines traced through males, while women exchanged in marriage provide the soft and perishable parts of the body. The creation of kinship substance may be as much a cultural as a natural process: Fox (1971a:245) notes that in Roti, bone is associated with the formation of social identity through the passing on of a geneaological name by the father, which depends on the payment of bridewealth just as much as on procreation itself; in the Trobriands, the perpetuation of matrilines involves as much cultural as biological work on the part of women (Weiner 1978). The contrast between blood and bone is drawn in order to make symbolic statements about degrees of incorporation of the child into specific kin groups, or to express distinctions between concepts of incorporation and alliance. Of most immediate concern to us here are the numerous instances in eastern Indonesia in which an ideology of asymmetrical alliance occurs in conjunction with the concept of blood and bone as gendered substances, where the 'flow of life' (Fox 1980) is in essence the flow of female blood between houses, as women commonly move at marriage to produce new life for their husbands' houses. ${ }^{2}$ Since no such groupings of bride-givers and bride-receivers are to be found in Toraja, it would in fact be surprising if blood and bone were sharply differentiated. We have seen already how individuals maintain multiple allegiances to different houses and at different moments may see themselves as part of different groupings of house descendants, while the membership groupings of particular houses also overlap each other.

Tato' Dena' gave the following account of conception and the development of the child in the womb, which clearly demonstrates the idea of men and women as basically similar beings, contributing equal amounts of equivalent substance to the formation of the foetus:

About this matter of the blood and bone: [at conception] the elo' (literally, 'spittle'; here used as a euphemism for 'sexual fluids') of our mother and father mingles together - because we begin as water (uai). And then we become solid (makko); we become complete, with all our fingers and toes (sanda rangka'), and we have breath/vitality (ta kepenawa). That is, we are completely formed, we pandiu (start to move in the womb so that the mother can feel it).

Although the father makes an initial contribution to the formation of bones in the foetus, the child ultimately derives more bone from the mother, because everything she eats and drinks in pregnancy continues to add to its substance. She eats cartilage (buku mangura) and hard things, so that the child will have

2 Whether women actually move to the husband's house in practice may depend on the amount of bridewealth paid by the husband's family. 
strong bones. However, the child will only be 'solid' if the father also assists its growth by having repeated intercourse with the mother and sleeping with her 'to keep her warm', like a hen sitting on her eggs. He must also avoid upsetting the mother or causing her grief (saki penaa), otherwise the child may be 'incomplete' (tangganna') or 'soft', that is, deformed (longgo'). Both parents must also avoid laughing at deformed people, neither should they have sexual relations with anyone except the spouse, metaphorically described as 'crossing the irrigation ditch' (ullamban kalo'). This close cultivation of the marital relationship, and its interweaving with the well-being of the child, suggests something of the intimate identification of parents and children which Benjamin (1994) also describes for the Temiar of peninsular Malaysia. The father is expected to be present at the birth of his child, often holding the mother from behind to support her while she squats in labour. It is his job to bury the placenta beside the house, and to take the birth cloths to the river to wash them. These are tasks which in some societies would be regarded as intensely polluting to men; the absence of any ideas of pollution associated with women's reproductive processes is indicative of the general muting of gender differences in Toraja society, about which I shall say more later. The bond between parents and child is further accentuated by teknonymy; if the first child is called Tanan, for instance, its parents will thereafter be known as Indo' Tanan ('mother of Tanan') and Ambe' Tanan ('father of Tanan'). When I questioned people about the possibility of seeing 'blood' and 'bone' as distinctively 'female' and 'male' substances, this was firmly denied; the reactions I received ranged from incomprehension to downright hilarity: 'Imagine, if your mother were all blood and your father were nothing but bones!'3 All my Toraja acquaintances were agreed in asserting the indivisibility of rara buku as kinship substance.

Interestingly, this idea is carried over, I believe, in attitudes to the preservation of corpses. Just like many other Indonesian peoples, Toraja practise lengthy, two-stage funerals and attach great importance to the preservation of ancestral bones, but their practices differ from those of Borneo peoples classically described by Hertz (1960) in one interesting respect. In Borneo, the conversion of the dead into ancestors requires the literal separation of bone and flesh, for Hertz noted the importance attached to cleaning the bones of any

3 I stress this point because Tsintjilonis (1999), on the basis of fieldwork done in the easterly district of Buntao', claims that people there do draw such a distinction. After widespread and repeated inquires I have been unable to receive any confirmation of this idea elsewhere in Toraja. In fact it was categorically denied, and most of my informants expressed disbelief at the possibility that any Toraja region could differ so fundamentally in its ideas. I remain puzzled by Tsintjilonis's data since it seems to stand in sharp contradiction to other principles of Toraja kinship. 
soft parts, prior to wrapping them for secondary rites. This final separation of soft from hard body parts marks the completion of the process by which the newly dead (sometimes thought of as dangerous to the living) are transformed into beneficent ancestors. Though Toraja have traditionally shared the idea that the preservation of the bones, and their periodic rewrapping, is essential if one is to tap the powers of the ancestors, no attempt is made to clean the bones and thus separate them from remaining traces of flesh. This stands in marked contrast also to many of the examples discussed by Bloch and Parry (1982), where the gendered associations of 'bone' and 'flesh' recur. On one occasion in Malimbong, a neighbour had opened his family tomb to make repairs, because rain water had been leaking inside and damaging the wrappings of the corpses. He took the opportunity to rewrap the remains of each of the ancestors, which were laid out on a rock, including a certain amount of black substance along with the bones of each. He pointed out to me in a cheerful and familiar way his mother, recognizable by one of her bracelets; though the sight was a strange one to me, it reflects a down-to-earth attitude combined with a feeling of comfortable intimacy with the dead which I find to be characteristically Toraja. Each ancestor was to be rewrapped in a small mattress, then bound with cloths, so that the end result would resemble the bolster-like wrappings of the dead at the time of their funerals. Far from manifesting any desire to separate bones and flesh, then, there seemed, on the contrary, to be a concern to keep them together and to prevent any visible diminution of the ancestors' remaining substance. I see this as a further reflection of the idea of rara buku as unified kinship substance in life.

\section{The centrality of siblingship in the conceptualization of kin relations}

Like the Malays (Carsten 1997:109), Toraja consider other substances to be kinship-creating, too, notably breast-milk. A child who has been fostered and breast-fed (disarak susu) by a woman not her mother becomes like a sibling to her foster-mother's children, so that they cannot marry. They are 'siblings in the milk' (to sisiunu' dio susu), or 'paired by the milk' (to dipasibali susu). Siblingship has been described as the key relationship in the bilateral kinship systems of Southeast Asia, exceeding in organizational importance that between parent and child. McKinley (1981:344) defines Malay kinship as essentially structured from 'sibling sets', which provide powerful lateral connections between people, although if looked at in terms of descent the social organization 'seems rather amorphous'. Carsten (1997:108) similarly defines siblingship as the 'core relation' among the Malays of Langkawi. McKinley argues that anthropologists, in their insistence on using descent as an analytical category, for long overlooked the importance of indigenous ideas of siblingship, which 
are actually their most distinctive feature. In such a system there are basically two categories, 'siblings' (kin) and strangers; in practical use the impulse is to include as many of one's relatives as possible within the sphere of 'siblings', to downplay precise degrees of difference (as between 'close' and 'distant' cousins) by calling them all 'siblings', and for even spouses to minimize the affinal quality of the relation between them by having the wife affectionately call her husband 'elder brother' while he calls her 'younger sister'. ${ }^{4}$ It is also typical for genealogical memory to be rather shallow, so that precise genealogical links between those who recognize each other as 'siblings' are forgotten. Rather than looking up towards apical ancestors, a downward focus on children, accentuated by teknonymy, accentuates the rapidity with which affines become kin. As soon as a marriage produces children, in-laws become united by their shared interest in them, since the children have rights of inheritance from both sides of the family. In Philippine bilateral kindreds Yengoyan notes that, just as among the Iban, 'affinal kin in one generation become cognatic kin in the next' (Yengoyan 1973:169). Errington (1987) proposes that the same structure of 'generational layers' of sibling sets is typical of the bilateral kinship systems of western Indonesia generally. This results in a horizontal type of organization rather than one focused on vertical, descent-based groupings. In the more hierarchical of these societies, different rules may pertain for lower- and higher-ranking persons: the rules actively prevent commoners from marrying very close kin, while first-cousin marriages are a preferred form among the aristocracy, who desire to conserve both status and property. This is the case in Luwu', as in some parts of Toraja. Where conservation of rank is an overriding concern, aristocracies everywhere are faced with a choice between two opposing strategies: they can either consolidate by marrying a very close relative, or else they may have to search far away for a marriage partner drawn from the highest ranks of a neighbouring society - hence the historical pattern of intermarriage between royalties of different kingdoms, whether in Europe or South Sulawesi. Of course such marriages also play an essential role in the formation of political alliances. Errington (1987:424-8) discusses in some detail the marriage strategies of the Luwu' nobility, and specifically the political motivations for aristocrats to control the marriages of followers:

[T] he high core wants to ensure that its followers will not marry too close to each other in order to prevent the formation of large rapu ('clumps') of densely interconnected siblings. Such a clump of solidary relatives might challenge the central high core itself. At the same time, it does not want its followers to marry people outside the core's kapolo, for the children might be outside the high core's authority. 
The solution is to arrange matches between third or fourth cousins for these people, while the highest ranking nobles themselves may marry first cousins, or attempt to marry further into the centre defined by the ruler and his court. Ruling nobles in Toraja did not have the same degree of control over networks of followers and lesser relations, but it is doubtless significant that it was in the more hierarchical central and southern areas that they had adopted the practice of marrying first cousins, while at the same time prohibiting commoners from doing the same. Was this explicitly to prevent the strengthening of kinship groupings that might rise to threaten them, or to hinder the consolidation of property among their inferiors?

Errington (1987:429) draws attention to the theme, prominent in Luwu' as in Balinese myths, of an incestuous union between siblings, or better still twins, as representing an ideal of closeness - one which however is disallowed, or triggers catastrophic results. It follows that 'the spouse is mythically and ritually a substitute for the sibling', from whom one must part because of the incest taboo (Errington 1989:237). In Java, twins of opposite sex are called 'God-given spouses' (Robson 1987:516). Toraja also say that they are 'married in the womb'. We have already encountered this mythical theme in Toraja, in the story of Sawerigading and his sister. I was told it had happened once at Buntu Pune' in Kesu' that a pair of opposite-sex twins were really married to each other on the grounds that Puang Matua had already married them in the womb; but according to the account I was given (which I am unable to confirm), their offspring were abnormal. ${ }^{5}$ The motif casts male and female not as radically different kinds of being, but as parts of the same primordial unity, who seek to reunite with each other - a theme widely echoed in Southeast Asian cosmologies. It also represents vividly the notion of siblingship as the ideal relation. This is reflected in real life in the reluctance to define others as non-kin, and in the underplaying of the affinal relation. This contrasts with those societies of eastern Indonesia where asymmetrical alliance is practised, and the relations between bride-givers and bride-receivers are correspondingly central and clearly defined.

In practical use, sibling terms can convey a variety of information. The possibility for simultaneous expression of both affection and a degree of agerelated hierarchy, where terms distinguish between older and younger, is one noted for the Malays but underplayed or ignored in Toraja, where distinctions on the basis of either age or gender are generally muted. Figuratively speaking, sibling terms stress an ideal closeness of relationship and the sort of cooperation and affection expected within it. Mata malotong na mata mabusa

5 The person who told me this came from a more northerly area, where even first cousin marriages are strongly disapproved of. His report clearly reflects the ambivalence that surrounds this theme. 
tae' na bisa dipasisala ('the black [iris] and the white of the eye cannot be separated') expresses this ideal of sibling solidarity. However, closeness can also mean competition and rivalry, and hence, sibling relationships are always likely to have an ambiguous quality about them. The desire to include large numbers of people in the 'sibling' category is a way of emphasizing the positive moral qualities of the relationship; but Toraja are perfectly well aware that real siblings are likely to feel competitive, rarely work together, and may fight over issues of inheritance. Sisarak tau do ampang - 'people part from each other on the threshold' - is a saying, typically and appropriately cast in a 'house' idiom, which signifies the reality that siblings have their own fortunes to seek, and that if they become the founders of new houses, only their direct lineal descendants will have rights in these. ${ }^{6}$

In Toraja, cousins are included in the category of 'siblings' (siunu' or siulu'), or of solata, 'one of us'. Within Toraja, solata refers to one's relatives, as opposed to 'others' (to senga'); outside of Toraja, any fellow-Torajan automatically becomes solata. It is possible to distinguish full siblings by the use of another term, common especially in the Sangalla' region. This is sile'to, from le'to, 'to split' (as, for example, firewood); sile'to has the sense of two halves split from a single whole. ${ }^{7}$ In Saluputti, sirondong, meaning 'close together', is more often used for full siblings, freeing siunu' to be used as a term for cousins or relatives in general. Even so, first cousins were often called sirondong as well. Rather than having fixed meanings, these terms seem to have constantly shifting referents. The effect is that precise degrees of collateral relationship are masked, in favour of creating an ideally seamless 'web of kinship', in which as many people as possible can be included in an undifferentiated way. Should one mistakenly suggest to a person that his kin tie is more distant than it really is, he might reproach one with the words: muserekki raraku, 'you are tearing my blood', implying that a split is being made in something which should be continuous. There is a word for cousins (sampu), who can also be distinguished by degree as first, second, third etcetera (sampu pissan, penduan, pentallun), but in practice there is an aversion to using these terms.

6 Compare Banks (1974:62) on Malay efforts to avoid putting too much pressure on the ideally intimate relations between kin, and Li $(1989: 8,81)$ on the expectations among Singapore Malays that kinship sentiment cannot be taken for granted, and that siblings will pursue separate futures.

$7 \quad$ Tammu and Van der Veen (1972:309) give the expressions sirondong lan mai tambuk ('together in the womb') and sile'to loloku ('split from my [that is, from the same] umbilical cord') (1972:489). The latter echoes Malay ideas that the placenta is somehow mystically the same one for all the children of a single mother (McKinley 1981:372; compare Volkman 1985:50). Other terms for siblingship which refer to the umbilical chord are renden lolo ('led by the [same] umbilical chord', as a buffalo is led by a rope) and polo lolo, which again implies the idea of sections 'cut from [the same] umbilical chord'. 
To inquire, as I did, about precise degrees of cousinship was considered disagreeable and rude. ${ }^{8}$

My inquiries were prompted by curiosity about how many people had actually married cousins. The general rule prohibits marriage with close cousins, up to and including third cousins. The prohibition could be circumvented by making a propitiatory offering, but in most parts of Toraja I found that violations of this rule, particularly by first cousins, still provoked strong feelings. It was only the nobility of the most hierarchical areas, Kesu' and the Tallu Lembangna, who had made themselves an exception to this rule. Here, the marriage of first cousins is a strategy which has for long been followed as a means of preventing the dispersal of property. 'Distant' cousins (sampu mambela), on the other hand, are very much preferred as spouses. But, given the general haziness of genealogical memory, I was puzzled as to how people could know who such distant cousins were. There is no term to distinguish marriageable from unmarriageable cousins, any more than there is for cross or parallel cousins; on the contrary, they were usually being classed with siblings anyway. Most people said that their parents told them who their cousins were, especially when they met at funerals or other ceremonies. But still, precise genealogical ties are rarely recalled. In my household survey of five neighbouring villages in desa Malimbong, I nonetheless found a high percentage of these preferred marriages. Out of a total of 61 marriages, only $5(8 \%)$ were between third cousins or closer; 29 (48\%) were between people describing themselves as 'distant' (fourth cousins or beyond); while 27 (44\%) were not related. In only one of the five marriages between 'close' cousins was the relationship closer than that of third cousins - in this case the couple were second cousins, though the husband (anxious, apparently, to downplay a too close relation) initially claimed that they were third cousins. Only four out of the 29 who were 'distantly' related could actually specify the degree of cousinship between them, still less trace the genealogical links between them. Instead, they said that they were 'siblings within the house' (siunu' lan tongkonan), or that 'their tongkonan joined' (sikande tongkonan), and all could name the houses that they had in common. It is houses that are remembered and serve to anchor relationships, filling the gaps left by lapses in genealogical memory even when a precise kin tie can no longer be traced. Once I had learned to ask about houses, people were no longer offended by my questions, but were happy to explain their relations in the way that they saw as appropriate.

8 A similar attitude is recorded by Banks (1974:63) for the Malays of Kedah, by Kemp (1983:86) for central Thailand, and by Bloch (1971b:81) for the Merina of Madagascar. In all these examples, kin terms are often extended to those with whom exact links may be unknown, and any denial of kinship is felt to be implicitly rude and hostile. 
Fractions of kinship substance

A most distinctive way of talking about kinship in Toraja is to treat descending generations as fractions of an original whole. Just as in the myth of Londong di Rura, Puang Matua split the betel nut into fractions to indicate different degrees of lateral relationship, so descending generations may also be talked about as fractions. Children are thus referred to as sangtanga or 'a half', grandchildren as sangtepo or 'a quarter', great-grandchildren sangleso or sangdaluk, 'an eighth'. Thus the expression sangtepo sangdaluk, 'grandchildren and great-grandchildren', has the general sense of 'one's descendants'. What we have here is an ego-centred way of talking about kinship as divisible fractions of inherited substance. It is not only the rara buku itself that is inherited thus, but also shared rights and responsibilities in origin houses, and potentially in inheritance. Everybody has a'pa' tepona, karua lesona, 'four quarters and eight eighths', in both ascending generations (one's grandparents and great-grandparents) and descending generations (one's grandchildren and great-grandchildren). ${ }^{9}$ One can begin to see why one Toraja man proposed that kinship could be thought of as a 'square', in which one could trace four ascending and descending generations from Ego, and four degrees of 'siblingship' laterally, from full sibs to third cousins. Of course this is not exactly the extent of ties in practice, for we have seen that lateral acknowledgement of more distant cousins is a desired feature (and ties with them may in practice be close, if for instance they live close by), while people often cannot name any ancestors beyond their grandparents and but rarely live to see their greatgreat-grandchildren. Still, I am struck by how closely this imagery aligns with the diagram of the Malay kindred produced by McKinley (1981:347), which also shows a set of nesting squares depicting the kindred as built up from sets of past sibling ties. This essentially ego-centred and symmetrical image lies at the core of Toraja kinship ideas, even though other images have their uses in particular contexts, whether it be the upward-looking genealogical concern with ancestors, or the downward-looking emphasis produced by teknonymy and the rules of inheritance.

Tato' Dena' used the same imagery of fractions of substance when I asked him how many tongkonan a person has. His explanation also shed light on the degree of responsibility one has to a house, depending on the closeness of the relationship. The relationship to one's parents' and grandparents' houses of origin will be the closest, and these are thought of respectively as 'a half' (dipiak tallang, literally, 'split in half like a bamboo') and 'a quarter' (ditepo

9 Compare Watson's (1991:69) description of the stress on cognatic modes of reckoning in south Kerinci, which people express in terms of their descent from 'four grandparents and eight great-grandparents'. 
Diagram 1. Toraja kinship terminology

\begin{tabular}{|c|c|c|c|}
\hline \multicolumn{4}{|c|}{ Generation } \\
\hline & +5 & \multicolumn{2}{|c|}{ nene' todoan (great-great-great-grandparent; todo = 'to touch') } \\
\hline & +4 & \multicolumn{2}{|c|}{ 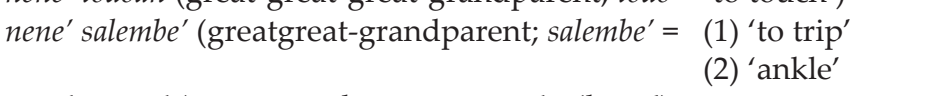 } \\
\hline & +3 & \multicolumn{2}{|c|}{ nene' guntu' (great-grandparent; guntu' = 'knee') } \\
\hline & +2 & \multicolumn{2}{|c|}{ nene' (nene' mammi') (grandparent; mammi' = 'delicious') } \\
\hline & \multirow[t]{2}{*}{+1} & ambe' (father) & pa'amberan (ambe' ure) (uncle) \\
\hline & & indo' (mother) & pa'indoran (indo' ure) (aunt) \\
\hline \multirow[t]{8}{*}{$(\mathrm{EGO})$} & \multirow[t]{3}{*}{0} & kaka' (older sibling) & sampu pissan (first cousin) \\
\hline & & adi' (younger sibling) & $\begin{array}{l}\text { sampu penduan (second cousin) } \\
\text { sampu pentallun (third cousin), etcetera }\end{array}$ \\
\hline & & \multicolumn{2}{|c|}{ siunu', siulu', sile'to (siblings) } \\
\hline & -1 & anak (child) & pa'anakan (anak ure) (nephew, niece) \\
\hline & -2 & \multicolumn{2}{|c|}{ атро (атро татmi') (grandchild) } \\
\hline & -3 & \multicolumn{2}{|c|}{ атро guntu' (great-grandchild) } \\
\hline & -4 & \multicolumn{2}{|c|}{ ampo salembe' (great-great-grandchild) } \\
\hline & -5 & \multicolumn{2}{|c|}{ ampo todoan (great-great-great-grandchild) } \\
\hline
\end{tabular}

Additional terms: sangrapu ('of one rapu') $\}=$ kin

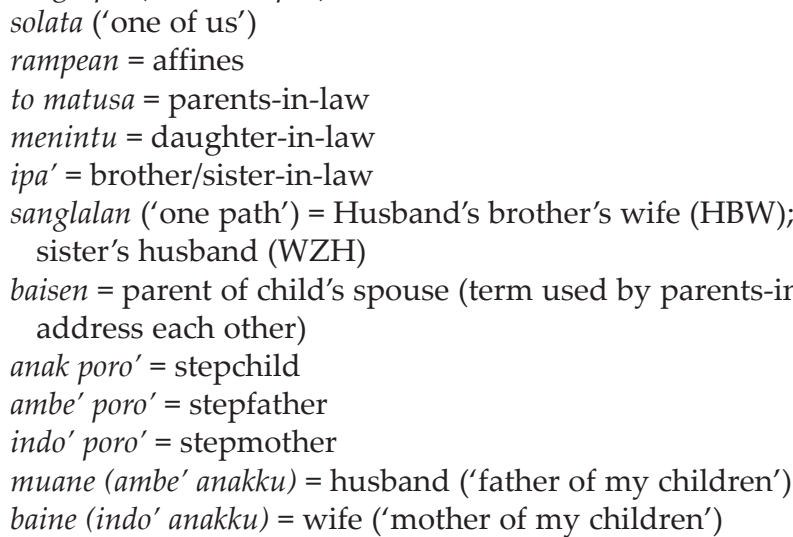

The terms muane and baine mean literally, 'man' and 'woman', and although they can also be used for the spouse, the latter, more indirect terms are considered more polite since they focus attention upon the parental role rather than the sexual relation between spouses.

$\left.a^{\prime} \mathrm{pa}^{\prime}\right)$; One has only an eighth (dileso karua) of substance and corresponding responsibility toward the tongkonan of one's great-grandparents, though one is likely to attend their house ceremonies; and one sixteenth (didaluk sangpuloannan) of a connection to the houses of one's great-great-grandparents. To these houses one is unlikely to maintain a close relationship unless one happens to be living in one of them. If it is a very important origin house, people are more likely still to be able to trace such a tie; if a lesser one, they may no 
longer have knowledge of these houses. Hypothetically, one might even be able to trace one thirty-second of a relationship (dibidang tallupulodua) to the houses of one's great-great-great-grandparents. This is not to mention the origin houses of one's spouse, to which in practice one will also be making ceremonial contributions.

Diagram 1 illustrates the features of Toraja kinship terminology. The terminology is basically generational, with no distinction made between cross and parallel cousins. There is a strong tendency to extend immediate kin terms - father, mother, grandparent, sibling, child, grandchild - to all relatives as well as to unrelated people in the appropriate generation, merging everyone of the appropriate status into a single category, or at most, two categories distinguished only by gender. Although the terms for siblings, as in other Indonesian languages, differentiate older/younger siblings ( $\left.k a k a^{\prime} / a d i '\right)$ rather than by gender, there is notably less stress on birth order and sibling hierarchy than is typical among the Malays (Carsten 1997:85-7). In fact, people tend to stress that older and younger siblings are 'the same'. Even the placenta, as mystical sibling, is not described as a 'younger' sibling, as among the Malays (Carsten 1997:83), or an 'older' one, as among the Makassar (Gibson 1995:136), but only as siulu', or as being 'born at the same time' (sangbara'l pada dadinna) as the child. It is noticeable that the terms for the more distant ascending and descending generations employ the organic, symmetrical imagery of the joints of the body as a measure of distance.

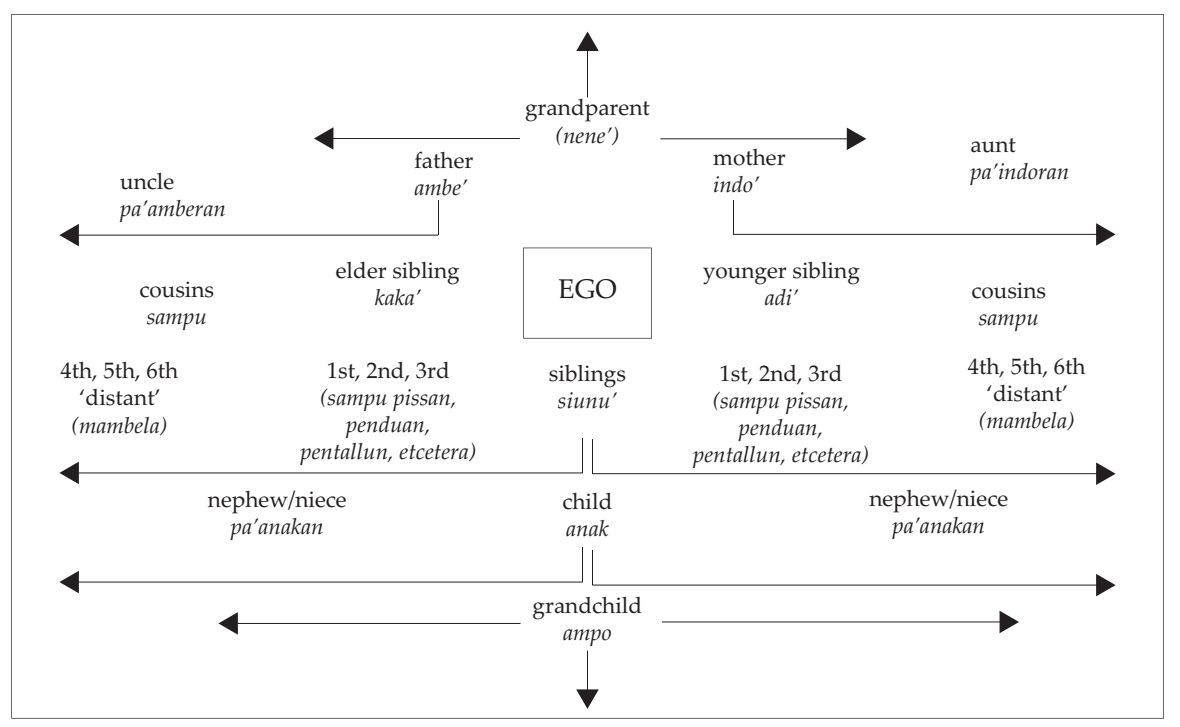

Diagram 2. The extension of kin terms 
Tracing kinship in terms of fractions of shared substance is a technique that can be used by extension to express rights in houses or property. Heritable rights and duties are divisible over generations in just the same way as rara buku is. Rights can also be doubled: for instance, if cousins from the same tongkonan marry, their children have rights 'twice', that is, through each of them, in that house. If they want to they may pay a double share of the expense when the house is being rebuilt - a move which would have the effect of tightening their link to that tongkonan, and increasing their prestige

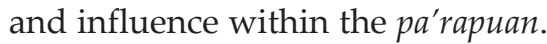

In the context of inheritance, we encounter a distinctive pair of terms, sarume and solong, which can be used deliberately to draw a distinction between 'immediate' and 'distant' relatives. Once again the imagery is botanical. Solong means the tough outer leaf which surrounds the young areca nut. As the nut ripens the solong falls off and the delicate inner leaf, the sarume, is seen. When a person dies, his or her children and grandchildren are termed sarume, and have the right to inherit property, while more distant relatives, the dead person's siblings and their children, are called solong. If a person dies childless, then his or her siblings and their children are treated as sarume and have the right to compete, by their funeral sacrifices, for the inheritance, while more distant kin still become the solong. Even more than the word rapu, these terms, which contingently emphasize boundaries and differences within the kinship grouping, are strictly context-bound.

A similar principle determines rights in tongkonan. Suppose, for example, that in a group of four siblings, one becomes wealthy and builds a fine house. Only his or her own children and grandchildren will consider the house 'theirs'. The other siblings and their children have no duty to contribute to its maintenance, nor do they have the right to attend its ceremonies. Shares of meat at ceremonies would not be expected to pass laterally from their houses to his. But if a descendant of one of our four siblings were to marry a descendant of the house founder, then a tie is created, for the children of this marriage will automatically acquire rights in the houses of both their parents. Since there is such a strong preference for cousin marriages, this in fact happens quite frequently. This sort of marriage is called sule langan banua, 'to return to the house' ('house' here having the sense of tongkonan). Other 'house' idioms recur in talking of matches between cousins. Casual sexual relations are strongly disapproved of in this context. One must not 'go in at the back of the house' (umpalao pollo' banua) or 'go through the window' (unnola pentiroan), like a lover visiting secretly at night. Instead one must make a formal proposal, or 'erect a stairway' (umpatendenni eran), as a go-between, who comes bearing betel nut to initiate a marriage proposal, comes up the front steps of the house. 
From siblings to affines, and back again

When kinship terms like siunu' are used inclusively, they carry the moral force of a desire to include as many people as possible within the ideally seamless web of kinship. But there are times when this principle is put to the test, for inevitably there are moments when distinctions do have to be drawn. Some of these moments have to do with deciding rights in houses and land. Others have to do with the question of affinity. When a marriage proposal is received from a cousin, people are forced to stop emphasizing their siblingship and redefine themselves as potential affines. But this punctuation of the ideal continuity of siunu' relations is only brief. Once the marriage has taken place, the couple is said to have 'returned to the house', and their consanguineal tie within the shared house of origin is re-emphasized, strengthened now by the new bond of marriage. Even a marriage between very distant cousins makes the link very close again; this is called 'renewing the blood and bones' (umbakarui rara na buku), or 'uniting the blood, uniting the bones' (umpamesa' rara, umpamesa' buku). Y.B. Tandirerung, remarking on the propensity of noble families to favour very close marriages, even between first or second cousins, for the sake of consolidating property, described the offerings made to appease the deities in such cases as 'tying together the blood and bones' (unnuppu' rara, unnuppu' buku). When this rite is performed, two priests (to minaa) perform a chant and make the couple swear an oath not to take the marriage lightly. As mentioned above, the aristocracy, having given themselves this latitude, appear to have had an interest in ensuring that their example was not followed by commoners; according to Tandirerung, drowning or exile were the penalties, in the past, for any commoners who married relatives closer than a third cousin - as severe as the penalties for a woman marrying someone of a lower rank. Some people still expressed strong feelings about first cousin marriage as a transgression inviting supernatural retribution. For Pak Kila', such a relationship was unnatural not least because it would turn siblings into parents-in-law (baisen), the closest of relationships into something more distant. 'How can siblings become baisen?' he exclaimed, 'What will they call each other? What will they say to each other?' This would seem to be a movement in the wrong direction, against the normal progression that transforms affines into kin. That transformation is expressed in another saying, in which the emphasis lies on the uniting of a couple through their children, who share their substance and who inherit rights and land from both of them. To sianak tae' na ma'din dipasisarak ('people who have had children together cannot be separated') does not mean that a couple cannot divorce, but that the rights of their children cannot be denied. Indo' Rapu', a woman from Ma'kale, cited this saying in discussing the possibility of a marriage between ranks. The children of such a union, she commented, could not be denied the right 
to be buried in the family tomb (liang) of the higer-ranking parent. Note the identification here between 'blood and bone' and its entailments of rank and inheritance; shared substance means shared rights as well.

Once cousins are wed, there is a particular concern about the possibly disruptive consequences of a divorce, when hurt pride, it is feared, might cause a distressing rupture in the newly strengthened kin tie. This is expressed as a fear that the blood and bones might be divided (dipasisala), smashed (poka) or destroyed (disanggang). This may even be used as an excuse politely to turn down a marriage proposal from a relative. Then people may say: 'Don't let us allow the blood and bones to be broken' ( $D a^{\prime}$ la poka rara, la poka buku). They might also turn away such a proposal by saying obliquely that 'siblingship wins out over marriage' (patalo kasiunuran na iatu kasibalian). This is indeed what must happen if a marriage between cousins does fail; then the relationship must be once again rethought, and must return to being one of siblingship as it was in the beginning, if the offended feelings of the two families are not to cause a serious rift between them. Then people must 'take each other as siblings [once again]' (siala siunu'). In the overall picture of Toraja kinship, then, the dominant theme is the ties between those who share the substance of 'blood and bone'. Inevitably, this continuity is punctuated periodically by those brief moments when affinal ties must be stressed. The clear idea that marriage should be exogamous (beyond the range of 'close' cousins) coexists with the deliberate blurring of degrees of cousinhood, and the absence of any clearly defined groups of the 'marriageable' and the 'unmarriageable'. In this sense Toraja ideas contrast most markedly with the ideologies of eastern Indonesian asymmetrical marriage systems.

Talk of relationships constantly refers back to the focus of links between houses, and in practice, ties are acted out through the maintaining of ceremonial obligations to houses. There are, as Toraja put it, two ways in which one may be linked with houses - either by blood or marriage. One is referred to as 'crossing the bridge of blood' (ma'tetean rara) and the other as the 'bridge of the birth of children' (tete ma'dadian bati'). Affines in general are termed rampean (rampe: 'side', 'party'; roughly, 'those of the [other] side'). Links formed by marriage, tenuous at first, grow stronger once children are born, because the children automatically inherit rights in the houses of both parents. Then husband and wife will be drawn into closer relations with each other's houses of origin. When two people marry, they are said to exchange parents (sisulle to matua). The expression basse situka', 'exchanged promises' (basse can also mean a sacred oath), signifies both the gaining of an extra set of parents, and the adoption of ceremonial responsibilities toward one's affinal relations. It is, in fact, in the context of ceremonial exchanges that these relationships are largely expressed. Great stress is laid on the ideal of balancing one's attentions to father's and mother's side, and of duties to affines with the mainte- 
nance of ties to one's own houses. These ties are not just taken for granted, but require to be publicly upheld and demonstrated through participation in rituals, and the giving and receiving of pigs and buffaloes which these involve. Failure to attend ceremonies will cause the blood and bone to snap $\left(k a^{\prime} t u\right)$ like a broken thread, or to be worn out (malusa), like an old cloth which after too many washings tears easily. Ceremonial participation must therefore be seen as not merely a reflection of already existing relations, but as part of their very substance. They are not only a means to make visible statements about relationships, but help to constitute those relationships and keep them alive. For affines, ceremonial duties are even more crucial to the relationship, for it is they in particular who are required to demonstrate sympathy at funerals by the presentation of sacrificial livestock. Most of the huge numbers of guests at funerals are there because they are related affinally to the hosts. Their spouses' siblings, in particular, bring large groups of their own villagers with them. Each gift of a pig or buffalo by an affine to a relative of the deceased becomes a debt which he or she must eventually repay with an equivalent animal at some later ceremony. Thus an endless series of pairs of credits and debts is created.

A person's interest in the houses of a spouse is also demonstrated in the effort which is often put in to repairing or renewing a house. Given the marked preference for uxorilocality in Toraja, it will often happen that a man puts his energies into rebuilding a house that belongs to his wife. If he and his wife are actually resident in the house, it is in their interest to do so. Of the 61 couples in my household survey, 45 (74\%) resided in the wife's house, or a house belonging to her family, not necessarily in her village of birth; 16 (26\%) lived in the husband's house or a house of his family. A man will also contribute toward the rebuilding of his own family's tongkonan, though if he is nonresident, his share of the expenses may be correspondingly smaller. Once the marriage has children, the interest in a spouse's origin houses becomes permanent. A childless person retains no interest in the houses of a spouse after divorce or death, whereas those who have children may continue to attend each other's ceremonies, because of their children, even after a separation.

An image of symmetrical and reciprocal relations between in-laws is enhanced by the singling out of two relationships which are given special terms. The parents of spouses call each other baisen, a term which corresponds to Malay and Javanese bisan or besan. ${ }^{10}$ A couple's parents ought to be friendly, and may develop exchange relations with each other. They are linked, initially, by an event which will take place in the future: the birth of

\footnotetext{
10 Carsten 1991, 1997:220; Robson 1987:514. The same relation in Bali is termed warang $(\mathrm{H}$. and C. Geertz 1975:171); Kemp (1983:86) also notes the existence of a term for the relation between parents-in-law in central Thai terminologies.
} 


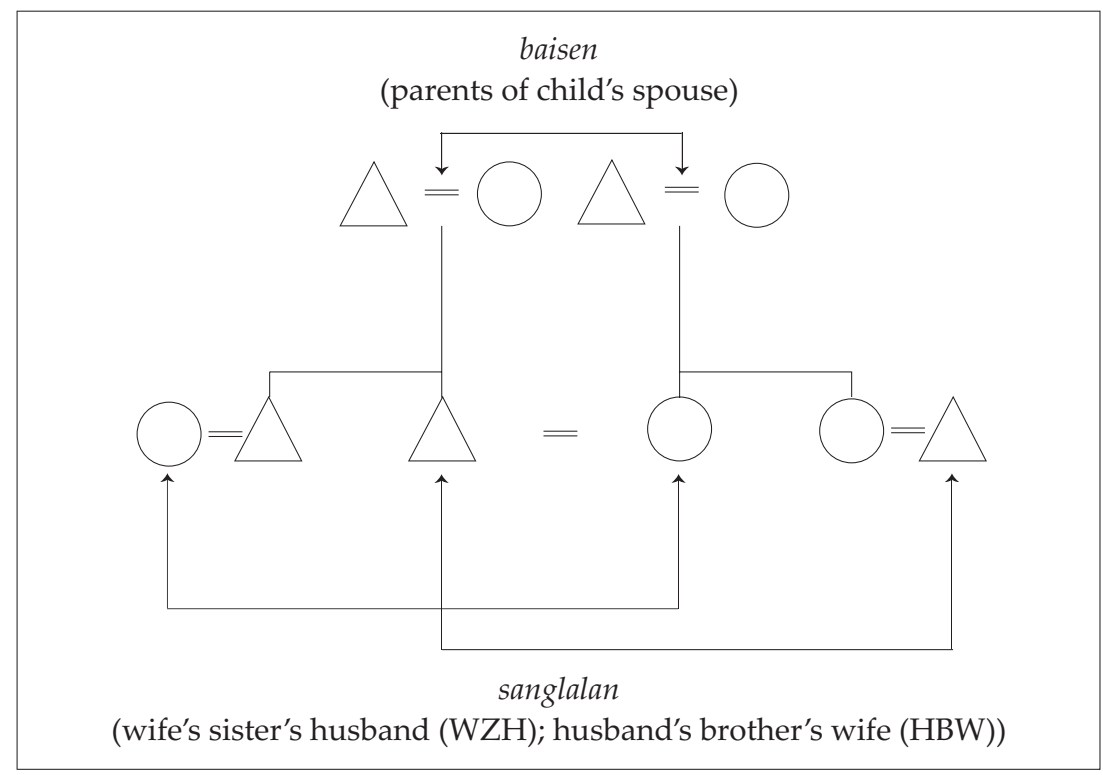

Diagram 3. Reciprocal ties between affines

children, who will eventually inherit from both of them. As with teknonymy, there is here a downward-looking attitude to descent rather than one which is ancestor-focused. This mutual interest in their grandchildren, over time, really may give rise to a close relationship, whose typical expression is the initiating of a ceremonial exchange; one friend explained how, since the birth of his grandchildren, his relations with his baisen had become warmer: they had brought a pig to his house ceremony, and later, he had reciprocated by taking one to theirs. Others noted that, in the case of a marriage between people of different ranks, the lower-status parents-in-law were likely to be more diligent in bringing pigs to the ceremonies of the higher-ranking, resulting in a flow of wealth toward the wealthy. A second affinal relationship which has a special designation is that of a person to the WZH or HBW (see Diagram 3). This is called sanglalan or 'one path'. ${ }^{11}$ The closeness of this relationship is left very much up to the individuals themselves, but again, the tendency is to express it in the form of ceremonial attendances and obligations. Where

11 A special term for this relationship is also found in Malay, where the spouse's sibling's spouse is termed biras (Carsten 1997:238); in Javanese the term is pripean (Robson 1987:514). Among Langkawi Malays, the relation is likely to become especially intimate between female co-parents-in-law, who are often closely involved in the rearing of their grandchildren. 
one party is wealthier or more influential than the other, the sanglalan tie may even be cultivated as a useful connection by both sides, the lower status party being especially diligent in lending his attendance at ceremonies. As with the rest of the kinship terminology, baisen and sanglalan do not define any group or category of affines; what they express is a symmetrical and reciprocal relation whose focus is a married couple (and their children). Ultimately, what links the sanglalan is probably the same as the mutual interest between baisen, namely, a concern with inheritance: their marriages give them access to land which may be inherited by their spouses and eventually passed to their children.

Affines, all the same, cannot remain affines for very long, given that with the birth of children, who inherit rights on both sides of the family, affinal ties become transmuted back into bonds of 'blood and bone'. Significantly, the shift is expressed yet again through the ceremonial context. At funerals, pigs presented by fellow-members of the pa'rapuan are called petuaran, a 'pouring out' of their feelings for the deceased, with whom they share the ties of 'blood and bone'. They are not regarded crudely as debts, although in the long run they should be repaid. Affinal prestations to the hosts, on the other hand, are called pamulle. A gift in the pamulle category is more directly calculated as a debt, and requires a reciprocal transaction; it must be repaid by an animal of equivalent size at a future rite held by the giver. Rather than a long chain of credits and debts, then, a sequence of paired transactions may follow each other over time, with the next gift initiating a new pair of events. But depending on the intensity of relations, and the chance occurrence of funerals providing suitable occasions for repayment, the time lag between prestation and counter-prestation can be quite long, with the result that children generally inherit a certain number of unpaid debts from their parents. When I questioned people closely about the point at which affinal relations can be said to be converted back into ties of 'blood and bone', they explained that for the children of a marriage, a debt pair must be paid off first, before pamulle relations are converted back into petuaran. Once again, then, the substance of relations is seen to be bound up in the economic transactions that are an integral part of ceremonial life.

As we have seen, the expressed preference for marriage with 'distant' cousins is matched in my data by a clear statistical preference. Of course, within the radius of the local community, where people have a large number of kin, the chances of marrying someone who is related are rather high. Parents make sure to introduce children to their cousins at ceremonies, so that they know who they are, but it can also happen that two people discover an attraction first, and then search out the links between them, finding that they are related. There are, however, some clearly stated strategic reasons for this preference, which chiefly have to do with the ceremonial commitments that 
are created between affines. First, people say if the potential spouse is related, one can more easily find out about the person and his family, or one already knows them. But more importantly, when a marriage takes place within the pa'rapuan, competition in the creation of ceremonial debts and credits will be minimized. Especially in Salputti, people emphasize the fact that within the pa'rapuan, 'we don't calculate', or 'we don't force each other' (tae' tasitukka'). They feel united by their shared blood ties and common interests, and will not be too exacting on one another. One will refrain, for instance, from showing too much concern about the exact size of a pig or buffalo being repaid, or putting pressure on others for rapid repayment of debts; and if someone really cannot find a pig for a ceremony, but comes 'only to sit' (no'ko' bang), just 'holding their armpits' (ma'koko kalepak), or arrives 'bringing only their buttocks' (sae bang umbaa pollo'na), relatives will be understanding and will not shame them. Between two unrelated families, on the other hand, competition can be very intense, the more so if they come from different areas, and the resulting expenditure is likely to be correspondingly burdensome. Those who have married into a family from a different region of Toraja may often be heard to complain about the demanding, arrogant attitudes of their in-laws, and the risk of one family shaming the other in public is a source of anxiety. Many people today feel pressed by the question of how to curb ritual expenditure. Those with limited resources would often prefer to be able to spend what they have on educating their children, giving them a chance to improve their circumstances. Large families put pressure on ever dwindling shares of rice land, making it impossible for all children to make a living from farming, so most families today hope to have at least one migrant member whose remittances will help to make ends meet at home. In some regions, especially in the north where the steep slopes of Mount Sesean limit the amount of cultivable land, nearly all young people have left their villages (Volkman 1985:134).

If there are political and economic reasons why people should traditionally have preferred to marry neither too close, nor too far away, today another option presents itself. This is to marry someone from outside Toraja altogether. In the past, as we have seen, travel was difficult and dangerous; within the modern nation state, the possibilities for movement are numerous, and the chances of meeting people of other ethnicities correspondingly higher. Several people pointed out to me the manifest advantages of this strategy. An educated spouse with good job prospects in another part of the archipelago means enhanced living standards and a wider network of contacts outside of Tana Toraja itself. Today here, as elsewhere, the educated prefer each other as spouses. One man even suggested that the old restrictions on marriage between ranks, which prohibited a woman from marrying down, had been replaced by a new, educational hierarchy. Like the slaves of 
the past, the illiterate were on the bottom rung of this ladder, while university graduates formed the new élite. The suddenness of social changes related to increased mobility was very noticeable in some genealogies that I collected; people whose parents had been among the first in their communities to travel and work outside of Toraja during the colonial period, had themselves almost all married non-Toraja, often people met while studying in other parts of Indonesia. Members of other ethnic groups sometimes express reservations about marrying a Toraja: by doing so, one becomes involved in ceremonial life and then will never be out of debt. But for Toraja, aquiring non-Toraja affines can be the most effective means to reduce one's exposure in the ritual economy, for they will not be participating in the system from which it is otherwise so difficult to extricate oneself. This willingness to accept complete outsiders as suitable, even especially desirable, marriage partners, shows the strategic 'inclusiveness' of kinship ideology being put to use in new ways to meet the changed circumstances of modern times. At the same time, as Kalimantan has become a favoured destination for young Toraja migrants of both sexes since the 1990s, an increasing number of them have met and married Toraja partners there. In this case, the parents may well express pleasure that their child has found a partner from the homeland, albeit from a different district; the fact that they are living so far away may mitigate the threat of affinal competition, since their ritual participation will in any case be curtailed by the expense of returning home. 